\title{
PARENTING PSIKOEDUKASI DALAM MENDUKUNG PERKEMBANGAN SOSIAL DAN EMOSIONAL ANAK USIA PRA SEKOLAH DI KOTA SURAKARTA
}

\author{
Insiyah*1, Endang Caturini Sulistyowati $^{2}$ \\ Poltekkes Kemenkes Surakarta Jurusan Keperawatan
}

\begin{abstract}
Background: Children in kindergarten are experiencing rapid growth and development. Supporting child development is not only the responsibility of the government but also the responsibility of parents, teachers and the surrounding community. Parents are expected to have a good understanding of the psychological child so that they can provide care and education that allows children to grow and develop according to their age. This study aims to determine the effect of parenting psychoeducation on the social and emotional development of pre-school children. Methods: This research used the method of "quasi experiment pre-post test with one group" with a total sample of 63 pre-school age children. Sampling was done using Non Randomized One Group Pretest Postest Design. Research data analysis was performed using SPSS version 23. Results: The results showed that preschool age children numbered 63 people consisting of $60.3 \%$ (38) people were male and the rest were female $39.7 \%$ (25). There was an increase in social development in preschool children whose parents received significantly higher parenting psychoeducation ( $p$ value 0,000) There was an increase in emotional development in pre-school children whose parents received significantly higher parenting psychoeducation ( $p$ value 0,000). Conclusion: The conclusion showed that there was a parenting psychoeducation effect on parents on social and emotional development of pre-school age children.
\end{abstract}

Keywords: Psychoeducation, Social and Emotional Development, Pre School Children

\section{PENDAHULUAN}

Masa prasekolah merupakan masamasa kritis proses perkembangan emosi dan sosial anak. Dukungan terhadap perkembangan anak diperlukan khususnya bagi orang tua, Untuk itu perlu dilakukan parenting psikedukasi pada orangtua selanjutnya untuk merangsang anak-anak mereka terhadap perkembangan sosial dan emosional anak pra sekolah.

Pelatihan orang tua berbasis kesadaran dapat menyebabkan penurunan tingkat stres orangtua. Memberikan orangtua suatu metode pengasuhan positif, berarti memberikan alat untuk menciptakan perubahan melalui sikap dan tindakan mereka sendiri(Anderson and Guthery, 2015). Anak-anak tumbuh diberbagai situasi dan latar belakang. Beberapa diantaranya hidup dalam kedaan serba berkecukupan namun yang lain dalam suasana yang terancam. Dalam keadaan yang terancam sebagai contoh, keberadaan orangtua sangatlah penting. Pada penelitian yang dilakukan oleh (ElKhani et al., 2019) menemukan bahwa penyesuaian anak terhadap stres masa 
perang tidak hanya bergantung pada respons dan kualitas individu, tetapi juga sangat signifikan pada ketersediaan dukungan yang mungkin mereka terima dari orang tua atau pengasuh mereka dan kualitas hubungan.

Dalam keadaan yang lain dalam kehidupan seperti biasanya, masih ditemukan adanya orang tua yang menterlantarkan anaknya. Anak-anak yang lebih kecil lebih mungkin dilecehkan di lingkungan keluarga. Anak perempuan yang lebih muda lebih mungkin mengalami pelecehan oleh pelaku tunggal, sedangkan semua anak laki-laki melaporkan banyak pelaku. Kasus- kasus pelecahan pada anak di Indonesia membutuhkan perhatian lebih dan harus segera ditindak lanjuti (Sari, Nulhaqim and Irfan, 2015).

Jumlah penelitian tentang parenting psikoedukasi yang mendukung perkembangan emosional dan sosial anak pra sekolah masih minimal meskipun parenting psikoedukasi untuk orang tua dengan anak bermasalah atau berkebutuhan khusus telah cukup tersedia. Penelitian yang dilakukan Nurmalitasari (2015) menjelaskan bahwa perkembangan mental emosional bagi usia prasekolah merupakan perkembangan dasar karena potensi otak anak dalam masa ini akan mempengaruhi kejiwaan anak. Masalah mental emosional yang tidak diselesaikan akan memberikan dampak negatif terhadap perkembangan anak, terutama terhadap pematangan karakternya. Penanganan dan menganalisis kebutuhan emosi anak usia prasekolah diperlukan deteksi dini tumbuh kembang. Melalui deteksi dini dapat diketahui penyimpangan tumbuh kembang anak secara dini, sehingga upaya pencegahan, stimulasi, penyembuhan serta pemulihan dapat diberikan dengan indikasi yang jelas pada masa-masa kritis proses tumbuh kembang.

Perbedaan penelitian ini dengan penelitian tentang parenting psikoedukasi sebelumnya adalah dalam design tindakan psikoedukasi yang dikemas dalam problem solving terapi yang bertujuan untuk meningkatkan kesadaran diri orang tua dalam menghadapai masalah selama parenting. Penelitian ini bertujuan untuk mengetahui pengaruh parenting psikoedukasi terhadap perkembangan sosial dan emosional anak pra sekolah.

\section{METODE PENELITIAN}

Penelitian ini menggunakan metode "quasi experiment pre-post test with one group". Pengambilan sampel dilakukan secara non acak sehingga rancangan ini sering disebut dengan Non Randomized One Group Pretest Postest Design. Penelitian dilakukan untuk mengetahui perkembangan emosional dan sosial anak pra sekolah sebelum dan sesudah diberikan perlakuan berupa parenting psikoedukasi dan problem solving terapi pada orang tua di wilayah kota Surakarta. Peneliti melakukan pengukuran sebelum perlakuan dan sesudah perlakuan dengan menggunakan kuesioner perkembangan sosial dan emosional yang dimodifikasi dari Brenchley (2017). Jumlah responden 63 anak prasekolah, umur 3-5 tahun.

$$
\text { Penelitian dilakukan di }
$$

pendidikan Prasekolah Alif Smart Surakarta, pada Juni-Agustus 2019. Analisis peneliti menggunakan uji dependen t-test (Paired t-tes).

\section{HASIL PENELITIAN}

Hasil penelitian terhadap 63 anak pra sekolah rerata umur 48,17 bulan 
dengan umur termuda 3 tahun (36 bulan) dan tertua 5 tahun( 60 bulan). Sedangkan proporsi anak yang berjenis kelamin laki-laki $(60,3 \%)$ lebih banyak dengan yang berjenis kelamin perempuan $(39,7 \%)$.

Tabel 1. Hasil Uji T Dependen Tentang Perubahan Rata-Rata Perkembangan Sosial Sebelum dan Sesudah Intervensi Parenting Psikoedukasi

\begin{tabular}{lcccc}
\hline Intervensi & $\boldsymbol{N}$ & Mean & $\boldsymbol{S D}$ & $\boldsymbol{p}$-value \\
\hline 1. Sebelum & 63 & 39.10 & 7.175 & 0,000 \\
2. Sesudah & 63 & 42.10 & 6.681 & \\
\hline \multicolumn{5}{c}{ Selisih } \\
\hline \multicolumn{5}{c}{ Ada peningkatan perkembangan } \\
sosial pada anak pra sekolah yang orang \\
tuanya mendapatkan parenting \\
psikoedukasi secara bermakna (p value \\
0,000), skor ini naik sebesar 3,000.
\end{tabular}

Tabel 2. Hasil Uji T Dependen Tentang Perubahan Rata-Rata Perkembangan Emosional Sebelum dan Sesudah Intervensi Parenting Psikoedukasi

\begin{tabular}{ccccc}
\hline Intervensi & $\boldsymbol{N}$ & Mean & SD & p-value \\
\hline 1. Sebelum & 63 & 36,62 & 6,207 & 0,000 \\
2. Sesudah & 63 & 40,33 & 6,193 & \\
\hline Selisih & \multicolumn{5}{c}{3.71} \\
\hline Ada & peningkatan & perkembangan
\end{tabular}
emosional pada anak pra sekolah yang orang tuanya mendapatkan parenting psikoedukasi secara bermakna ( $\mathrm{p}$ value $0,000)$, skor ini naik sebesar 3,714 .

Tabel 3. Hasil Uji T Dependen Tentang Perubahan Rata-Rata Perkembangan Sosial dan Emosional Sebelum dan Sesudah Intervensi Parenting Psikoedukasi

\begin{tabular}{lcrcc}
\hline Intervensi & $\boldsymbol{N}$ & Mean & SD & p-value \\
\hline 1. Sebelum & 63 & 75.71 & 10,905 & 0,000 \\
2. Sesudah & 63 & 82.43 & 10,537 \\
\hline Selisih & \multicolumn{4}{c}{6,72} \\
\hline \multicolumn{4}{c}{ Ada } & peningkatan perkembangan \\
sosial dan emosional pada anak pra \\
sekolah yang orang tuanya mendapatkan \\
parenting psikoedukasi secara bermakna \\
(p value 0,000), skor ini naik sebesar \\
6,714
\end{tabular}

\section{PEMBAHASAN}

Pada penelitian terdahulu memberikan alasan yang senada tentang manfaat psikoedukasi keluarga di mana psikoedukasi keluarga berisi tentang penyakit, pengobatan, dan manajemen perawatan; koordinasi layanan; memperhatikan harapan semua pihak, reaksi emosional, dan kesusahan; bantuan untuk meningkatkan komunikasi keluarga; pemecahan dan instruksi masalah terstruktur; menerapkan strategi koping dan rehabilitasi secara individual; memperluas jaringan dukungan sosial; dan perencanaan krisis eksplisit dengan keterlibatan professional (Farlane, 2016). Psikoedukasi keluarga dalam penelitian ini dikemas dalam bentuk problem solving terapi dimana orang tua difasilitasi untuk memahami pengetahuan tentang perkembangan emosional dan sosial anak Pra sekolah dan secara berkelompok menjalin komunikasi dan berinteraksi dengan peer untuk mengidentifikasi permasalahan yang dihadapi selama merawat anaknya yang duduk di bangku taman kanak-kanak.

Penelitian yang terkait dengan intervensi melalui orang tua anak atau pengasuh dilakukan terhadap keluarga dengan gangguan jiwa oleh (Chiocchi et al., 2019). Semua sesi terdiri dari presentasi power point, menguraikan 
berbagai elemen yang akan dibahas, pengasuh menyelesaikan latihan dalam sesi dan juga mengakhiri sesi berdasarkan pengalaman mereka sendiri sehingga mereka kemudian dapat memahami bagaimana anggota keluarga mereka mengalami kesulitan. Evaluasi dari dampak intervensi psikoedukasi yang dipimpin pengasuh pasien dengan gangguan jiwa terdapat tiga hasil yaitu: peningkatan kesejahteraan mental, pengurangan beban dan pemberdayaan yang didukung oleh rekan sejawat harus didorong dan didukung.

Kebanyakan orang tua mengakui bahwa mengasuh anak, walaupun memberi banyak manfaat dalam banyak hal, bisa menjadi tugas yang sulit dan kebanyakan akan mengatakan menginginkan bantuan dalam mengasuh anak dari waktu ke waktu. Di masa lalu, banyak bantuan yang ditawarkan untuk orang tua meskipun bantuan tersebut bersifat apa adanya dan tidak bersifat memberdayakan orang tua. Profesional datang ke rumah dan memberi tahu orang tua apa yang harus dilakukan tanpa pemahaman, atau simpati untuk masalah yang dihadapi keluarga dalam kehidupan sehari-hari. Pada akhir yang paling bermasalah dari model pengasuhan ini telah mengakibatkan orang tua kehilangan anak-anak mereka karena orang tua dianggap telah kasar atau lalai. Pendekatan yang berbeda untuk mengasuh anak sangat penting sehingga tantangan adalah salah satu yang perlu diambil dengan tetap menghormati variasi budaya dan memberdayakan orang tua untuk menawarkan yang terbaik bagi mereka ke anak-anak (Stewart-Brown, 2014). Memahami proses keluarga dari waktu ke waktu terkait dengan ibu, ayah, dan bayi sangat penting dalam mengidentifikasi dengan lebih baik mereka yang berisiko, dan menginformasikan upaya perawatan yang ditujukan untuk keluarga (Berryhill, Soloski, Durtschi, \& Adams, 2016).

Meningkatnya skor perkembangan sosialdan emosional anak pra sekolah tidak lepas dari peran orang tua yang selalu menemani anak dalam kesehariannya. Menurut (Berryhill, Soloski, Durtschi, \& Adams, 2016), jika bayi secara teratur merespon rangsangan baru dengan reaksi emosional yang intens dan tangisan, orang tua dihadapkan dengan tugas yang sulit untuk menenangkan bayi ini yang menunjukkan peningkatan level emosionalitas negatif. Orang tua menghabiskan energi mereka untuk merawat bayi sehingga mungkin memiliki lebih sedikit energi untuk memenuhi kebutuhan mereka sendiri, termasuk kebutuhan hubungan pasangan. Persepsi orang tua tentang emosional bayi memiliki kaitan dengan stres parenting dan kualitas hubungan pasangan atau ibu dan ayah setelah kelahiran bayi di atas usia anak 1, 3, dan 5 tahun.

Hasil penelitian menunjukkan bahwa persepsi ibu dan ayah tentang emosionalitas bayi dan stres pengasuhan terkait dengan kualitas hubungan (Berryhill, Soloski, Durtschi, \& Adams, 2016). Pada penelitian yang lain, seorang ibu mendiskusikan kesulitan yang dihadapi karena kurangnya keterlibatan ayah. Ibu dalam sampel sering menggambarkan tantangan yang dihadapi karena kurangnya keterlibatan ayah. Seperti yang disampaikan oleh seorang responden bahwa ia menjadi ibu tunggal dan sangat sulit berurusan dengan ayah dimana ayah tidak selalu siap ditempat ketika dibutuhkan. Ia hanya merasa perlu menghabiskan lebih banyak waktu bersama anak-anak mereka dan harus 
menghadapi stres itu serta menjelaskan kepada anak-anak mengapa ayahnya tidak datang atau tidak memperhatikan anak (Montgomery, Chaviano, Rayburn, \& McWey, 2017).

Seorang ibu atau ayah yang bertanggung jawab mengasuh anaknya memerlukan dukungan dan dalam penelitian ini dukungan dalam bentuk parenting psikoedukasi mampu mengubah perkembangan sosial dan emosional anak pra sekolah. Sejalan dengan penelitian terdahulu yang menggunakan data dari 99 ibu yang mendaftar dalam model pengasuhan Mom Power (MP) intervensi, penelitian ini berusaha memahami faktorfaktor yang mempengaruhi keterlibatan dan retensi peserta. MP adalah intervensi awal berbasis kelompok. Program didasarkan pada teori yang memanfaatkan wawancara motivasi sebagai komponen inti untuk meningkatkan keterlibatan program.

Tujuan studi adalah untuk menjelaskan secara kualitatif alasan mengapa para ibu tertarik untuk berpartisipasi dalam program ini, termasuk apa yang mereka harapkan dari pengalaman tersebut, dan untuk menguji secara kuantitatif sejauh mana kehadiran dikaitkan dengan faktor-faktor demografis, pengalaman, dan psikososial. Melalui analisis wawancara, ibu mengungkapkan bahwa ia mengharapkan intervensi MP untuk menyediakan lingkungan yang hangat untuk diri mereka sendiri dan anak-anak mereka serta untuk mendukung dan meningkatkan pengasuhan mereka, dan $95 \%$ mengungkapkan harapan mereka bahwa intervensi akan membantu mereka tumbuh dan berkembang sebagai wanita (Mucka et al., 2017).
Dalam penelitian ini semua orang tua mengikuti sesi yang diberikan dan sebagian lain meringkas sesi lebih cepat dari yang direncanakan. Hal yang sama terjadi pada penelitian sebelumnya dimana tingkat kehadiran relatif tinggi, dengan $62 \%$ ibu kehilangan kurang dari satu sesi intervensi dalam kelompok. Analisis kuantitatif menggunakan regresi berganda untuk asosiasi uji faktor demografi, pengalaman, dan psikososial dengan tingkat kehadiran tidak signifikan. Hasil menunjukkan bahwa motivasi wawancara mungkin merupakan komponen penting dalam mempromosikan upaya keterlibatan peserta dalam intervensi pengasuhan anak(Mucka et al., 2017).

Harapan tentang intervensi MP. Enam puluh empat ibu memberikan tanggapan tentang harapan mereka untuk mendapatkan bantuan dari Intervensi kelompok MP. Secara keseluruhan, 44 ibu menyebutkan harapan terkait dengan mendapatkan bantuan untuk anak mereka, 58 mencatat harapan terkait untuk meningkatkan pengasuhan mereka, dan 61 melaporkan harapan terkait dengan memperbaiki diri. Empat ibu mengidentifikasi satu jenis harapan, 21 menggambarkan dua jenis, dan 39 mencantumkan ketiga jenis. Empat puluh empat ibu merespons dengan harapan jatuh ke dalam kategori bantuan untuk anak dan ingin belajar tentang pemisahan anak (4 ibu), cara mengeluarkan kepribadian anak mereka (5 ibu), dan bagaimana membantu anak mereka belajar lebih banyak tentang cara mengatasi (7 ibu). Para ibu berharap kelompok itu akan menjadi menyenangkan dan lingkungan sosial (10 ibu) yang menyediakan tempat untuk anak-anak mereka untuk bermain dan berinteraksi dengan anak-anak lain (17 ibu). Lebih dari setengah dari para ibu 
termasuk harapan untuk intervensi MP untuk mendukung perkembangan anakanak mereka (44 ibu) (Mucka et al., 2017).

Hasil penelitian menunjukkan bahwa kepuasan pola asuh memediasi hubungan antara kedua dimensi manajemen kondisi keluarga (kesulitan hidup keluarga dan mutualitas orangtua) dan depresi. Secara khusus, keluarga yang lebih besar kesulitan hidup dan mutualitas orangtua yang lebih rendah ikaitkan dengan kepuasan pengasuhan yang lebih rendah, yang, pada gilirannya, dikaitkan dengan tingkat depresi yang lebih tinggi (Salvador, Crespo, \& Barros, 2019).

Empat komponen yang dapat ditafsirkan dari pengasuhan ibu, termasuk parenting pendukung (supportive parenting), kesenangan sendiri (selfenjoyment), parenting yang luar bias (overwhelmed parenting )dan parenting yang penuh kasih (affectionate parenting) (Unternaehrer et al., 2019). Suatu penelitian yang bertujuan untuk menyelidiki efektivitas behavioral parent training (BPT) untuk anak-anak prasekolah dengan perilaku yang mengganggu dan untuk mengeksplorasi prediksi tanggapan orang tua yang melibatkan orang tua dari 68 anak prasekolah, berusia antara 2,7 dan 5,9 tahun, dapat dievaluasi adanya erubahan dalam perilaku anak-anak setelah BPT dengan pretest-posttest satu kelompok desain. Hasil didasarkan pada laporan orang tua dari intensitas dan jumlah masalah perilakunya. Variabel prediktor termasuk kurangnya perhatian orang tua, perilaku antisosial, dan penggunaan alkohol, dan efikasi dan disiplin diri pengasuhan ibu. Hasil penelitian menunjukkan bahwa masalah perilaku anak yang dilaporkan ibu tidak berubah dalam periode menunggu tetapi membaik secara signifikan setelah BPT $(d=0,63)$. Penggunaan alkohol tingkat tinggi oleh ayah dan kadar alkohol rendah, disiplin ibu yang tidak efektif masing-masing dikaitkan dengan hasil yang agak buruk. BPT dalam kondisi perawatan rutin jelas meningkatkan perilaku mengganggu di anak-anak prasekolah. Ibu yang menganggap diri mereka tidak memadai dalam mendisiplinkan dan ibu yang mitranya tidak mengkonsumsi alkohol tingkat tinggi melaporkan peningkatan terbesar (van der Veen-Mulders, Hoekstra, Nauta, \& van den Hoofdakker, 2018).

\section{KESIMPULAN DAN SARAN}

Ada peningkatan perkembangan sosial dan emosional pada anak pra sekolah yang orang tuanya mendapatkan parenting psikoedukasi lebih tinggi secara bermakna demikian ada pengaruh parenting psikoedukasi pada orang tua terhadap perkembangan sosial dan emosional anak usia pra sekolah.

\section{DAFTAR RUJUKAN}

Anderson, S. B. and Guthery, A. M. 2015 'Mindfulness-based

psychoeducation for parents of children with attentiondeficit/hyperactivity disorder: An applied clinical project', Journal of Child and Adolescent Psychiatric Nursing, 28(1), pp. 43-49. doi: 10.1111/jcap.12103.

Berryhill, M. B. et al. 2016. 'Family process: Early child emotionality, parenting stress, and couple relationship quality', Personal Relationships, 23(1), pp. 23-41. doi: 10.1111/pere.12109.

Brenchley, J. F. M. 2017. 'SocialEmotional Development 
Assessment: "Scale Development for Kindergarten through Second Grade Youth Universal Screening'.

Chiocchi, J. et al. 2019. 'Can a carer (peer) led psychoeducation programme improve mental health carers well-being, reduce burden and enrich empowerment: a service evaluation study', Journal of Mental Health Training, Education and Practice, 14(2), pp. 131-140. doi: 10.1108/JMHTEP-10-2018-0057.

El-Khani, A. et al. 2019. 'Caregiving for children through conflict and displacement: a pilot study testing the feasibility of delivering and evaluating a light touch parenting intervention for caregivers in the West Bank', International Journal of Psychology. doi: 10.1002/ijop.12591.

Farlane, W. R. M. C. 2016. 'Family Interventions for Schizophrenia and the Psychoses: A Review', 55(3), pp. 460-483. doi: 10.1111/famp.12235.

Montgomery, J. E. et al. 2017. 'Parents atrisk and their children: intersections of gender role attitudes and parenting practices', Child and Family Social Work, 22(3), pp. 1151-1160. doi: 10.1111/cfs.12332.

Mucka, L. E. et al. 2017. 'Mixed-Methods Evaluation of Participant Recruitment and Retention in the Mom Power Parenting Intervention Program', Infant Mental Health Journal, 38(4), pp. 536-550. doi: 10.1002/imhj.21652.

Nurmaguphita, D., Keliat, B. A., \& Putri, Y. S. E.2018. Penerapan Terapi Kelompok Terapeutik Kanak-Kanak dan Psikoedukasi Keluarga pada Anak dan Orangtua Terhadap
Perkembangan Otonomi Anak, 1(1), 14-23.

Nurmalitasari, F. 2015. Perkembangan Sosial Emosi pada Anak Usia Prasekolah. Program Magister Psikologi Fakultas Psikologi Universitas Gadjah Mada; Buletin Psikologi (23) 2.

Salvador, Á., Crespo, C. and Barros, L. 2019. 'Family Management of Pediatric Cancer: Links with Parenting Satisfaction and Psychological Distress', Family Process, 58(3), pp. 761-777. doi: 10.1111/famp.12379.

Sari, R., Nulhaqim, S. A. and Irfan, M. 2015.'Pelecehan Seksual Terhadap Anak', Prosiding Penelitian dan Pengabdian kepada Masyarakat, 2(1), pp. 14-18. doi: 10.24198/jppm.v2i1.13230.

Stewart-Brown, S. 2014. Parenting Interventions to Promote Wellbeing and Prevent Mental Disorder, Wellbeing. doi: 10.1002/9781118539415.wbwell03.

Unternaehrer, E. et al. 2019. 'Dissecting maternal care: Patterns of maternal parenting in a prospective cohort study', Journal of Neuroendocrinology, (July), pp. 115. doi: 10.1111/jne.12784.

Van der Veen-Mulders, L. et al.2018. 'Preschool children's response behavioural parent training and parental predictors of outcome in routine clinical care', Clinical Psychology and Psychotherapy, 25(1), pp. 1-9. doi: 10.1002/cpp.2117. 